\title{
Extent, timing and palaeoclimatic significance of glaciation in the High Atlas, Morocco
}

Link to publication record in Manchester Research Explorer

\section{Citation for published version (APA):}

Hughes, P. D., Fenton, C. R., Fink, D., Schnabel, C., \& Rother, H. (2012). Extent, timing and palaeoclimatic significance of glaciation in the High Atlas, Morocco. In Quaternary International (pp. 210-210)

\section{Published in:}

Quaternary International

\section{Citing this paper}

Please note that where the full-text provided on Manchester Research Explorer is the Author Accepted Manuscript or Proof version this may differ from the final Published version. If citing, it is advised that you check and use the publisher's definitive version.

\section{General rights}

Copyright and moral rights for the publications made accessible in the Research Explorer are retained by the authors and/or other copyright owners and it is a condition of accessing publications that users recognise and abide by the legal requirements associated with these rights.

\section{Takedown policy}

If you believe that this document breaches copyright please refer to the University of Manchester's Takedown Procedures [http://man.ac.uk/04Y6Bo] or contact uml.scholarlycommunications@manchester.ac.uk providing relevant details, so we can investigate your claim.

\section{OPEN ACCESS}


Understanding their erosive capability is key to unravelling the complex coupling of climate and the dynamics of the solid earth. Recent studies have focused on quantifying rates of glacial erosion to provide key data for understanding the physics that drives glacial erosion. While these studies concur that glacial erosion can outpace fluvial erosion, the magnitude of the measured erosion rates varies from $>>10$ to $<1.0 \mathrm{~mm} / \mathrm{yr}$. This discrepancy is, in part, because these studies estimate erosion rates over vastly different spatial and time scales, and in regions of differing tectonic activity. One excellent region for addressing the long-term, orogen-scale impact of glaciers on the landscape is the tectonically quiescent Transantarctic Mountains (TAM) that have been glaciated since 34 Ma. Recent geomorphic investigations in the region of Byrd Glacier (the largest glacier in the TAM) indicate that the current geomorphology reflects ancient fluvial and tectonic processes active in the Cretaceous through Eocene, suggesting minimal reshaping of the landscape by glacial processes during the past $\sim 34 \mathrm{Ma}$. A new suite of apatite fission track thermochronology (AFTT) ages support the geomorphic evidence of minimal glacial erosion in the Byrd Glacier region. Cretaceous through Oligocene cooling ages along the $80 \mathrm{~km}$ extent of the Byrd Glacier valley wall reveal a maximum of $\sim 5$ $\mathrm{km}$ of erosion in the last $\sim 32 \mathrm{my}$. These results are in marked contrast to Quaternary AFTT ages commonly observed in glaciated terranes, that relate to erosion rates $>2 \mathrm{~km} / \mathrm{my}$. In light of the high ice velocities of the Byrd Glacier, and the evidence of water at the base, these surprisingly low erosion rates challenge the current paradigm that erosion rate scales simply with ice flux. These results indicate that critical physics is missing from our glacial erosion laws.

\section{VOLCANIC MOUNTAINS, RIVER VALLEYS AND SEACOASTS - THE PALEOENVIRONMENT OF HOMO ERECTUS IN EASTERN JAVA (INDONESIA)}

O. Frank Huffman. University of Texas at Austin, United States

E-mail address: huffmanof@mail.utexas.edu

The Homo erectus fossil discoveries of eastern Java record more than a million years of life and death along large rivers draining stratovolcanoes, a setting similar to present day. Andesitic conglomerate and sandstone dominate the Homo erectus-bearing formations and make up well-known discovery deposits at Ngandong, Mojokerto, Sangiran Dome and Trinil. The Homo erectus stratovolcanoes, judging from those in modern Java, supported montane forests and perennial river flow by concentrating rainfall orographically and produced pyroclastic eruptions and volcaniclastic sedimentary pulses, including long-run-out lahars (LLs). LLs originate as debris flows and extend $15-120+\mathrm{km}$ downriver as slurries and sandygravelly floods. The Ngandong Homo erectus bonebed evidently was deposited by an LL flood along the middle reach of Java's largest river, the Solo, $\sim 50 \mathrm{~km}$ from a volcano, following mass death in a population aggregation of large mammals. Similarly, the Trinil bonebed probably originated as an LL descending a forested volcano into wet lowlands. The Mojokerto deposit, situated more distally in a coastal paleogeographic location, formed as a fluvial-gravel bar in the river-dominated delta where the ancestral Brantas River, subject to LLs, entered the sea $\sim 100 \mathrm{~km}$ from the source stratovolcano. Most Sangiran contexts likewise occur in fluvial volcaniclastic facies. Cattle, deer, Stegodon and other large-bodied herbivores-found as transported bioclasts at the sites-inhabited the river drainages with Homo erectus. The paleoenvironment of the Java discovery district, comprising $<1 \%$ of the total land area of Indonesia, was especially favorable to Homo erectus occupation and fossilization. Aquatic-, forestand large-mammal dietary resources, present along stratovolcanic rivers, evidently sustained recurring or continuing Homo erectus habitation, while rapid volcaniclastic deposition, at times following eruption-related death, promoted preservation of skeletal remains.

\section{D ARCHITECTURE AND EVIDENCE OF MULTIPHASE SEDIMENT-FILL WITHIN DRUMLINS FORMED BENEATH A PALAEO ICE STREAM}

Leanne Hughes. British Geological Survey, United Kingdom

E-mail address: lean1@bgs.ac.uk
Ice streams play an important role as regulators of the behaviour of modern ice sheets, taking the form of corridors of fast flowing ice. Similar zones of fast moving ice have also been recognised draining the margins of the Late Weichselian British and Irish Ice Sheet. One of the largest of these is the Irish Sea Ice Stream which fed ice from its source in southern Scotland, through the Irish Sea Basin where it merged with ice issuing from the ice caps formed over Ireland and Wales, eventually reaching as far south as the Isles of Scilly. Part of the 'footprint' left by this palaeo ice stream are the drumlins and related bedforms found on Anglesey, NW Wales. The sediments and structures contained within these subglacial landforms provide a comprehensive record of the processes occurring beneath this palaeo ice stream. Sections through three drumlins exposed on the coast of western Anglesey has revealed that the drumlins are composed of two units of clast-rich subglacial traction till: (i) a lower, massive to weakly stratified diamicton derived from the underlying metasedimentary bedrock; and (ii) an upper, stratified, sandy diamicton containing a higher proportion of far travelled clasts. The stratification within the tills mimics the overall shape of the landforms. The lower part of this till sequence is cut by a number of laterally extensive, subhorizontal to inclined sediment-filled hydrofractures that are interpreted as having formed during the later stages of landform development; possibly in response to decompression associated with ice stream shutdown and/or thinning of the ice sheet. The internal 3D architecture of the drumlins, coupled with the variation in till composition upward through the sequence indicates that these landforms developed as a result of several phases of sediment-fill. This multiphase or pulsed model of drumlin development is thought to record the fluxing of sediment down-ice beneath this part of the Irish Sea Ice Stream.

\section{EXTENT, TIMING AND PALAEOCLIMATIC SIGNIFICANCE OF GLACIATION IN THE HIGH ATLAS, MOROCCO}

Philip Hughes. University of Manchester, United Kingdom E-mail address: philip.hughes@manchester.ac.uk

Glacial geomorphological mapping, 10Be terrestrial cosmogenic isotope analyses and palaeoglacier-climate modelling in the highest peaks of the Atlas Mountains, Morocco $\left(31.1^{\circ} \mathrm{N}, 7.9^{\circ} \mathrm{W}\right)$, provides new and novel data toward understanding the history and evolution of the largest desert region on Earth. The Atlas Mountains display evidence of extensive and multiple Pleistocene glaciations. The largest ice field and valley glaciers formed in the Toubkal massif. Here, the oldest moraines have yielded $10 \mathrm{Be}$ ages scattered in the range 74-31 ka. A later phase of glaciation is dated to c. $24 \mathrm{ka}$. Moraines belonging to a third phase of glaciation has yielded a series of very close exposure ages (within error) at around $12 \mathrm{ka}$, and falling within the Younger Dryas (12.9-11.7 ka). The glacial record of the High Atlas effectively reflects moisture supply to the north-western Sahara Desert and can provide an indication of shifts between arid and pluvial conditions. The low altitude of the glaciations in all three glacial episodes indicate that climate was not only significantly cooler than today, but also very much wetter. The new evidence on the extent, timing and palaeoclimatic significance of glaciations in this region has major implications for understanding moisture transfer between the North Atlantic Ocean and the Sahara Desert during Pleistocene cold stages. The findings are highly significant for understanding atmospheric circulation during pluvial phases recorded in the Sahara, such as during the African Humid Period at the Pleistocene/Holocene transition (15 to $6 \mathrm{ka}$ ). Glacier advance in the High Atlas during this interval provides insight into the seasonal distribution of precipitation and provides valuable insight into the respective roles of moisture supply from the North Atlantic depressions and the West African Monsoon. This in turn then has important bearing on the strengths of meridional vs. zonal circulation at mid-latitudes during pluvial phases.

\section{ICE CAPS IN THE BALKANS: THEIR, EXTENT, AGE, AND PALAEOCLIMATIC SIGNIFICANCE}

Philip Hughes. University of Manchester, United Kingdom

E-mail address: philip.hughes@manchester.ac.uk 
Ice caps covered large areas of the Balkans during cold stages of the Quaternary. In Montenegro, the largest ice caps (>1000 km2) extended over the Durmitor, Sinjajevina and Moraia massifs. At lower elevations, on the Adriatic coast, a smaller ice cap (165 km2) developed on Mount Orjen (1894 $\mathrm{m}$ ) in response to locally very high precipitation. The glacial deposits in all these areas are dominated by limestone-derived sediments and secondary carbonates in till units can be dated using uranium-series methods. Detailed field mapping allied to 30 uranium-series ages from glacial sediments has allowed a new model of Quaternary glacial history to be developed for the Balkan Peninsula. This is in good agreement with recent work in the Pindus Mountains of Northern Greece. The most extensive glaciation in Montenegro took place during the Middle Pleistocene (correlating with a major phase of glaciation in Greece) during MIS 12 (c. 480-430 ka). Later and less extensive glaciations are recorded in cirques and valleys across Montenegro and these correlate with glaciations during MIS 6 (190-130 ka) and MIS 5d-2 (110-11.7 ka) also recognised in Greece. In the Durmitor massif, the highest in Montenegro, valley glaciers were present during the Younger Dryas (12.9-11.7 ka) and confirm the influence of North Atlantic Ocean circulation on Pleistocene climate change in this part of the Mediterranean. A small cirque glacier survives today on Durmitor because of locally favourable topoclimatic conditions. This paper presents these new data and discusses their palaeoclimatic significance for this part of southern Europe and the wider Mediterranean region.

\section{FRONTAL POSITIONS OF MARINE-TERMINATING OUTLET GLACIERS OF SE GREENLAND SINCE THE LITTLE ICE AGE: RESULTS FROM HELHEIM AND KANGERDLUGSSUAQ}

\section{Anna L.C. Hughes. Swansea University, United Kingdom}

E-mail address: A.Hughes@swansea.ac.uk

Remote sensing observations have shown that the marine-terminating outlet glaciers of the South-East (SE) sector of the Greenland Ice Sheet (GrIS) have simultaneously increased in speed, thinned and retreated (and subsequently slowed down) within the last decade. The large and coupled nature of these changes has raised concerns about the future stability of the ice sheet and driven a renewed interest in discovering the controlling factors. Extending the record of change is critical, both to set current changes in context and to provide appropriate datasets to validate and improve numerical models of outlet glacier behaviour. Vegetational trimlines (abrupt transitions between bare and vegetated fjord walls) mark the maximum late Holocene lateral extent (Little Ice Age (LIA); 11501850) of the outlet glaciers and provide the means to reconstruct former ice margins and past thinning rates. We present an 80-year timeseries of measured glacier margin positions for the two largest marine-terminating outlet glaciers of SE Greenland (Helheim and Kangerdlugssuaq), and additionally infer the LIA frontal positions. Calving front positions were digitised from oblique and aerial photographs, maps and satellite imagery (declassified spy data; Landsat, ERS and Envisat SAR). Trimlines were identified and mapped from aerial photos and maximum-likelihood classification of multispectral satellite imagery based on spectral differences between bare and lichen-covered rock. Results reveal differences in the retreat trajectories of the two glaciers since the LIA. Kangerdlugssuaq exhibits more-or-less continual retreat with fastest rates in 1930s and mid2000s. At Helheim the present-day (2010) frontal position replicates that of the 1930s and the 1981 position is close to the LIA maximum. This indicates that despite high retreat rates observed in the mid-2000s, Helheim has not contributed significantly to mass loss from the GrIS since the 1930s.

\section{FLOW PATTERN EVOLUTION OF THE LAST BRITISH ICE SHEET}

Anna L.C. Hughes. Swansea University, United Kingdom

E-mail address: A.Hughes@swansea.ac.uk

Deglaciated landscapes record the cumulative action of the ice that sculpted them, providing both spatial and temporal constraints on ice sheet shape and form. Although relatively small and accessible, the British landscape has been underused in attempting to reconstruct a unified flow pattern configuration and evolution of the last British Ice Sheet (BIS). We use systematic countrywide mapping of the terrestrial record of glacial landforms (subglacial lineations and ribbed moraine, eskers, meltwater channels, and moraines) from satellite and airborne imagery to establish the flow patterns of the BIS. One hundred flowsets identified on the basis of parallel conformity, morphometry, orientation, and superimposition of lineations document multiple readjustments of flow configuration during the last glacial cycle. Using an inversion approach guided by current understanding of glacial landform genesis we convert the cacophony of flowsets into ten glaciologically plausible stages of ice sheet configuration. Combined with a semi-independently reconstructed pattern of retreat and published chronological information we present an ice sheet-scale landform-based reconstruction of the evolution of the last BIS. A picture emerges of a dynamic ice mass with two dominating configurations. Ice expanded out of central Scotland to merge with multiple peripheral ice centres, and with the Irish and Scandinavian Ice Sheets. Widespread ice sheet thinning driven by ice streaming precedes topographically guided retreat to multiple independent ice domes located over high ground. Our glimpses of ice sheet shape and form at distinct timeslices record key ice sheet geometries and could be used as powerful tests of numerical models of ice sheet growth, evolution and decay.

\section{RAPID EARLY HOLOCENE RETREAT OF HELHEIM GLACIER, SOUTH-EAST GREENLAND}

Anna L.C. Hughes. Swansea University, United Kingdom

E-mail address: A.Hughes@swansea.ac.uk

Fast-flowing marine-terminating outlet glaciers are the principle route for ice loss from the Greenland Ice Sheet (GrIS). Determining the response of such glaciers to rising temperatures is essential to predicting the ice sheet's contribution to sea-level rise. In the last decade the outlet glaciers of the south-east (SE) have exhibited dramatic and synchronous changes in speed, retreat, and thinning rates, temporarily doubling the GrIS contribution to sea-level rise. In addition to plugging a major gap in the deglacial chronology of the GrIS, constraining the longer-term retreat rates and timing of the glaciers of SE Greenland is essential to provide a context for recent changes and evidence to constrain and validate numerical modelling of future changes. We present constraints on the rate and timing of retreat of ice from Sermilik Fjord, the former drainage route of the second largest outlet of SE Greenland, Helheim Glacier. In situ cosmogenic nuclide $\left({ }^{10} \mathrm{Be}\right)$ exposure dating reveals extremely rapid deglaciation of the fjord; following initial recession from the fjord mouth at $\sim 11 \mathrm{ka} \mathrm{BP}, \sim 80 \%$ of the $80 \mathrm{~km}$ long fjord was deglaciated within 1000 years. Bedrock-erratic pairs from low elevation sites spanning the central $50 \mathrm{~km}$ of the fjord show a simple deglacial history, with ages overlapping within uncertainty limits. Retreat is coincident with rapid temperature increases recorded in the Greenland ice cores and existing evidence dating the local marine limit to $\sim 11$ ka BP. Potential pinning points suggested by the fjord bathymetry do not appear to have slowed retreat. This evidence indicates a significant response of this former outlet glacier to climatic amelioration and high sea-levels at the start of the Holocene. We will also report additional exposure dating inland of an island at the head of the fjord. These dates will test whether rapid retreat continued beyond this topographic obstacle and constrain the timing of separation of Helheim from neighbouring outlet glaciers.

\section{TEXTURAL CONTROL ON THE WEATHERING OF BASIC IGNEOUS ROCKS: A MICROMORPHOLOGICAL APPROACH}

Sajid Hundekari. Department of Geology, Poona College, Camp, India E-mail address: sajid_hundekar@yahoo.com

The micromorphological studies on the rock weathering have shown that basalt during the early stages of weathering shows strong mechanical fracturing. Labradorites are slightly to moderately altered while augites are moderately to strongly altered. In their most advanced stage of weathering the labradorites and augites are highly to completely alterd thereby indicating higher to highest degree of alteration. In the initial stages of weathering of dolerite; labradorites and augites still possess their identity with labradorite showing nuclei of alteration at their centers. However 